\title{
Armed Alley: An Anti-War Novel Fraught with Both Ideological and Artistic Insights
}

\author{
Guangzhen Li \\ Shandong Normal University \\ Jinan, Shandong, China 250012
}

\author{
Kenn Kurumisawa \\ Waseda University \\ Tokyo, Japan
}

\begin{abstract}
Armed Alley basing itself on the five three Massacre in Jinan, is forbidden for distribution on the very day it goes for publication. The novel really thought-provoking reveals the truth behind the five three Massacre wrought by Japanese imperialists. Readers are amazed by its clear narration, simple wording and wonderful plot. It is an excellent anti-war novel with both ideological and artistic insights.
\end{abstract}

Keywords-Armed Alley; Kuroshima Denji; anti-war Novel; The five three Massacre in Jinan

\section{INTRODUCTION}

Kuroshima Denji, a famous Japanese proletariat writer is the author of Pig Herd, Two-penny Nickel, which are widely read in China and selected for Japanese Textbook for many times. Armed Alley is his only long novel, which is based on the 5. 3 Massacre in Jinan in 1928. As a work with both ideological and artistic insights, the novel has been put under a ban every since its appearance because it violates the " 6 must-nots for wartime composition" by the Japanese authorities.

From October to November 1929, Kuroshima Denji had carried out field investigation in Jinan, after which, he went to Tianjin and Fengtian (Renamed Shenyang now) to collect materials. He finished the Armed Alley after returning to Japan, which was published in 1930 by Nippon Hyoron Sha Co., Ltd but was put under censoring and a ban at the very day. After WW II ended, the censoring and ban on the novel were still kept because the description of America, England, France and other imperialist powers invading China still went against the publishing ordinance at that time. The novel finally got published by Aoki Shoten Publishing Co., Ltd, in July 1953, 10 years after the author passed away. In fact, even in the Aoki Soten version, there is some some sensitive content being abridged by the Japanese authorities. Only after the Three Volumes of Complete Works of Kuroshima Denji went into press in 1970, has the reader been able to see the original content of Armed Alley.

\section{II. "THE IMPORTANT FORT OF JINAN"}

After entering Jinan Massacre (so called in Japan) into search engine in Japanese website, usually comes up the explanation which says the massacre was resulted from the Japanese living in Jinan being assaulted there. However, in
Armed Alley, the "Japanese being Assaulted" means Japanese spies appearing everywhere in streets of Jinan, who finds excuses either by making stories out of nothing or by reckless self-playing, then send the troop to Jinan under the pretext of protecting Japanese compatriots. After the Japanese army came to Jinan under the pretense of protecting Japanese compatriots, they put all the banks and factories under protection instead of their compatriots. In order to make the Administration mobilize troops from Japan to China, they used Japanese people as bait and seduce the Chinese to kill them. Description in the novel and record of history coincide in this aspect, which proves it is the real thing happening in 1987. What were the troops of Jiang Kaishek doing then? What were the Japanese troops doing then? What were the Japanese in Jinan doing then? What were the Americans, the English and the French doing in Jinan then? Why does Jinan become the battlefield? Armed Alley by Kuroshima Denji gives all answers.

In 1928, in order to fin ish the cause unifying China, the Nationalist Government waged the 2nd Northern Expedition. Japan, fearing the appearance of a unified China, react quickly by sending soldiers to Shandong in a view to impeding the northern expedition. On April 7, Jiang Kaishek arrived at Xu zhou City, which signifies the official start of the 2 nd northern expedition. Then the Japanese authorities dispatch 5,000 soldiers from the 6th Military Division to Jinan under the pretext of protecting their Japanese compatriots. The fact is on April 24, Jiang Kai-shek gave orders "when our troop arrives at Jiaozhou-Jinan Road, we must protect foreign people and be patient with the Japanese lest conflicts may happen. All publicity materials harmful to diplomatic relation between Japan and China are forbidden for releasing. Presenting peace is all important" (1). Compromising and resigning before the Japanese however further inflates their ambition to invade. They purposefully picked up the fight, which grew on May 3 from small to extensive between armies of the two countries. The Japanese spares no mercy in killing Cai Gongshi, the diplomatic commissioner of the Nationalist Government. On May 10, the Japanese Army conquered Jinan. In this conflict, 25 Japanese soldiers died while soldiers and common people of China being killed or wounded amounted to thous ands.

\footnotetext{
(1) Nanjing Nationalist Government Documentary, compiled by Zhu Hanguo, Anhui People's Press, 1993, P56.
} 
Why would Japan send army to Jinan? "Jinan is an important fort of China"(2). A sentence incited in the novel by Kuroshima Denji from The Special Interests between Japan and Manchu and Mongolia works as an adequate footnote for the novel, which says in order to protect its interests from being taken back by China or taken away by other European or American powers, Japan has guarded Jinan as a lifeline only second to Manchu and Mongolia in importance, because along the railway from Qingdao to Jinan there have about $1,800,000,000 \mathrm{t}$ coal which combine with coal from neighboring Shanxi Province account for $80 \%$ of Asian coal reserve at that time.

It is natural that resource-scarce Japan will drool over such a bountiful reserve of coal. Th is is the main reason why Japan would attach such importance to Jinan and would send troop there.

\section{BURGEONING OF COMMUNIST IDEOLOGY AMONG JAPANESE SOLDIERS}

The match factory run by a Japanese -- Jinan Fulong Match Company serves as a main arena where many activities in the novel happened.

Chinese workers under his pen were exploited as slaves. Indentured laborers aged about 7 or 8 and female workers fought for their life under miserable conditions. Capitalists supervised laborers closely, who are allowed neither freedom to go nor wages. From time to time they would be punished by cudgeling or whipping. During waves boycotting Japanese products, the Japanese stuck labels of "made by China" to the highly toxic matches made of yellow phosphorus and sold them. The Chinese workers were exposed to toxic substances like yellow phosphorus, etc which eroded their fingers and jaws and sickened many of them. Not only in Jinan, but also in Tianjin, Dalian, Fengtian (present Shenyang), Jilin and Changchun, etc, the Japanese capitalists operated factories producing matches of yellow phosphorus. However, as early as 1921 , it was forbidden in Japan to produce matches with yellow phosphorous. Japanese soldiers witnessing the scene felt shocked were they not dispatched here to protect their compatriots? Why did they see Japanese torturing Chinese workers? The phenomena of Japanese bullying Chinese there prompted them to think why are we coming? Whom did we come to here to protect ?

The novel not only exposes the miserable conditions under which the Chinese laborers worked but also reveals the truth about "Japanese Compatriots". In Jinan, people dealing in opium, morphine, cocaine, heroine, codeine belong to the soft-class, which is mainly comprised of Japanese... Right here there might be about 1,000 Japanese engaging in the business" (3). People overseeing Chinese laborers in match factories are mostly bullies and gangsters from gangdoms in Japan. The Japanese soldiers began to understand they were

\footnotetext{
(2) Armed Alley, by Kuroshima Denji, trans Li Guangzhen, Shandong People's Press, 2015.4, P83.

${ }^{3}$ Armed Alley, by Kuroshima Denji, trans Li Guangzhen, Shandong People'sPress, 2015.4, P28.
}

here for another reason. Seeing the miserable Chinese laborers, they began to sympathize with them and tried to stop violence of their compatriots. On the other hand, they got to know what the American and English people were doing in Jinan. They give helps to Jiang Kai-shek so as to expand their sphere of influence in Jinan.

The novel also writes about wig factories run by Englishmen in Jinan. From the factory name, we see that they use hairs as raw material for production. Therefore, they fixed eyes on plaits of the Chinese. Facing the Chinese who insisted on keeping his plait, the Englishmen have made a rule: tax must be paid to keep plaits. Thus, the Englishmen profited themselves by using hair grabbed from the Chinese to produce wigs. Thus, we can see how the American and European powers exploit Chinese people in Jinan. Cases like this do not come alone in the novel. People living in Jinan at that time were heavily exploited and looted by Japanese, American and European powers. It is because of these truthful depictions irritating sensitive nerves of the imperialists the novel was banned from distributing.

In War Against Wars -- Collection of Anti-militarism Works (compiled by Japanese Leftist Writers in Nansong Academy in May 1928), a proletariat work published in 1927, is included another anti-war and anti-militaris $m$ work by Kuroshima Denji, called "sledge". The backdrop of the novel is at Siberia where Japanese troops were also stationed. For destroying the Russian Revolution Administration newly born in 1917, Japan joined hands with American and European powers in 1918 to wage wars against Russia. During 4 years' battle, more than 3,000 Japanese soldiers died. And Kuroshima Denji was in the army right then. He wrote the novel from his own experience which deeply exposed the felony committed by Japan in trying to kill the new born Russian Revolution Administration, which makes the novel a famous proletariat work. Japanese soldiers at Siberia used all their strength to loot local people, they broke into poor farmers' home and took their livestock, grains and any other things that may have a value. All necessities for mobilizing and battling are obtained from local families through robbing. This is what the Japanese soldiers in Siberia did then. In fact, those soldiers looting poor local people were themselves from poor family in Japan. When they saw the tragedy of local people being robbed and bullied, they saw themselves being maltreated in Japan and began to sympathize with the local people. Their attitudes toward the war began to change, which brought them into contemplation: at whom will they point their guns? Who gives the order to shoot? Why they shoot? Bit by bit, the war-weary mood began to grow in the army and small-scale mutinies happened from time to time. At battling, soldiers pointed their guns at the Japanese who ordered them to shoot instead of their so-called enemies. A war between Japan and Russia unknowingly turned into a war between Japanese -- Japanese soldiers began to shoot each other. This is what the novel "Sledge" mainly talks about.

In Armed Alley, there are similar scenes. When Japanese soldiers stationed at Jinan Furong Match Co., Ltd saw how the Japanese there tyrannized the local people they began to feel for the workers under oppression, which also 
brought them to think: are we here to protect our Japanese compatriot? Why are we here? Are we doing the righteous thing? They grabbed the whip from the Japanese supervisor and threw it away. Rebelling Japanese soldiers were put to death secretly and buried with false honor of "dying courageously in battle". When the information came to Japan, the Japanese at home misunderstood they were killed by Chinese soldiers which ignited their hatred against Chinese soldiers and give the Japanese authorities another pretext to mobilize more troops to China. This is where the novel ends. It is their time to be executed when Japanese soldiers began to sympathize their enemies and feel confused about mission to guard Japanese compatriots.

Such excellent masterpiece have been buried from our sight for such a long time.

\section{ARTIST IC EXPRESSION WITH CHARMS}

There are reviewers who once give the follow comment on Armed Alley: "it criticizes face to face the invasion against China by militarist Japanese Government and calls for unification of proletariat people from China and Japan. To some extent the novel weighs more in politics than in art. As a literary work it may be flawed by overemphasizing revolution at the expense of art, however, its clear-cut political theme has the power to make people feel shocked"(4). Is this the truth? As the first one who translated the novel into Chinese, I have a completely different viewpoints.

- In aspect of description, the novel tell the story in a clear and objective way while in aspect of plot, the novel uses straightforward narration followed by an unexpected ending, which makes the work highly readable.

For example, 53 years old Nakatsu was the military consultant of Zhang Zongchang the former superintendent official of Shandong Province. He was a hardhearted person. At the home of Inawataro, a supervis or of the match factory, he was affected by the long-died feelings among town folks and feel in love with Inawataro's sister, the 20 years old girl called Reiko. The novel described very vividly they psychology of Nakatsu in love with the young girl, which makes the readers believe that Nakatsu who is "more frightening than horse thieves "(5) would change completely to live a good life. Following the readers' logic, Nakatsu being tortured for finding a way to make love to Reiko must love Reiko truly. At the end, Nakatsu chose to ask some gangsters to take Reiko away forcibly. According to their plan, if Reiko stayed with the 3 years old Chiro, they would take both of them away to Tianjin. And if he wouldn't like Reiko anymore he would "just sell her". "6 "just sell her", one sentence exposes reservedly gangsterdom of Nakatsu. At last, when these bunch of gangsters found that Reiko had run

\footnotetext{
${ }^{4}$ Class Agreement Transcending National Border and Ethnicity. Li

Yannan. Journal of Guangdong University of Education, Issue of June 2006.

(5) Armed Alley, by Kuroshima Denji, trans Li Guangzhen, Shandong People'sPress, 2015.4, P63.

(6) Armed Alley, by Kuroshima Denji, trans Li Guangzhen, Shandong People'sPress, 2015.4, P187.
}

away, they robbed Reiko's family. Their plan to take Reiko away becomes a plan for robbing. "The robbery for a girl turned into one for valuables",? ${ }^{, 7}$ which starts the alley war in the city.

The death of Yamazaki is very surprising. As a secret agent, Yamazaki for facilitating his work learned very well Chinese lifestyle, who spoke Chinese as well as local people and were often seen wearing the Chinese long garment, even his action of blowing nose was the same with the Chinese. He was also very proud of this. However, on the other land, he embezzled payments for information, smuggled drugs and spread rumors. Finally, he lost himself in his so-called great cause-- he provided exaggerated information to Japan hoping to give them new reason to send more troops to China and help Japan earn more interests from China -- in his mind there is a beautiful picturing unrolling itself, "as a Japanese he imagined in a good mood: by making up information about cruel facts and letting the Japanese hear of it, they will be instigated. So I must tell them the information, must let them know! ... Who did it? I must let them think it is the Chinese who did it" ${ }^{8}$, while lost in such thought, he did not hear the Japanese sentry asked him to freeze and continued walking. Then he was shot to death by the sentry who mistook him for a Chinese.

- Simple and concise wording, especially the use of local languages makes the novel more true to life and give more charms to the novel.

Names of places appearing in the novel like streets, factories and railway stations all use real names at Jinan of that time. For example: Likou, Shiwangdia, Weishan Road, Mingshui, Guodian, Jiaozhou-Jinan Railway, TianjinPudong Railway, Antique Store at Weiwu Road, Yellow River Railway Bridge, Wangsherenzhuang Tavern, Guanyi Street, Liyuan Gate, Weiyi Road, Puli Gate, etc. So are the names of cities and regions, like Xuzhou, Lincheng, Yanzhou, Taian, Suzhou, Xuzhou, Lincheng, Taishan Mountain, Qingdao, Zhoucun Village, Dalian, Jieshou, Yellow River, Tianjin, etc, which are stilled used today. Furong Match Company (later called Jinan Match Factory, which was consolidated by Shandong Bohai Group Co., Ltd in 1994) and other factories though have become part of history, they still could wake people's memory about that time. Moreover, the novel also directly uses Chinese spoken by local people in Jinan, which makes the novel more vivid and true to life. On the destroyed Liyuan Gate carved three sentences in Chinese “誓雪此耻” (Vow to revenge the invasion) ‘你看见么? '(Do you see it?) ‘你记得么?' (Do you remember it?), which ignite people's anger. ${ }^{9}$ The three Chinese sentences on the gate reveals Jinan people's indignation for the 5. 3 massacre and the novelist's sympathy with the Jinan people.

\footnotetext{
${ }^{8}$ Armed Alley, by Kuroshima Denji, trans Li Guangzhen, Shandong People'sPress, 2015.4, P191.

(8) Armed Alley, by Kuroshima Denji, trans Li Guangzhen, Shandong People'sPress, 2015.4, P206.

(9) Armed Alley, by Kuroshima Denji, trans Li Guangzhen, Shandong People'sPress, 2015.4, P231.
} 
- On characterization, though a great number of characters appeared in the novel, even the soldier presenting only for a moment are given a full description. No matter it is Inawataro the Chineseworker-sympathizer, or Takatori the Japanese soldier or Wang Hongjie, the Chinese laborer, or $\mathrm{Ma}$ Guanzhi and his wife who saved Ichirox the novelist all gave them a vivid all-round description. In his description of the Taro's family life, the novelist presented every reader with a true presentation of the everyday life of the Japanese in China.

Though a lot of characters appeared in the novel, development of the story is strictly logical and reasonable. Of the story, the later parts often echo with the former ones, which helps the story to reach climax and leads the reader to one after another afterthoughts. Therefore, for this perspective, the novel is not only powerful in ideological aspect but also touching in artistic expression.

\section{CONCLUSION}

The Military Authority of 1920s and 1930s' Japan once laid down the following rules concerning literary creation of Japanese writers:

- It is forbidden to write about Japanese army being defeated.

- It is forbidden to write about killings of Japanese army in the battle.

- It must write about the hatred against Chinese army.

- It is forbidden to write about the whole picture of war.

- It is forbidden to write establishment and codes of the army.

- It is forbidden to write soldiers as ordinary people. (10)

Reading through the Armed Alley, we see that the novel violate all the 6 rules above. After finishing the novel, Kuroshima Denji went to live on a small island in his hometown Shikoku to rehabilitate from lung disease. But because of his proletariat literary works, he was under constant and close supervision of the secret police. In this year we celebrate the 70th anniversary to remember the victory of the Anti-fascist war and the 87th anniversary to remember the Jinan Massacre. I believe rereading this excellent anti-war work with both ideological and artistic insights will give another vantage point to know about historical truths of that times.

On the campus of Waseda University international students from China can be seen from time to time, of which, those from Shandong Province are of no small number. I once asked them which Japanese writer's work have they studied or known about back in China most of them answered Haruki Murakami. And when being asked have they ever read proletariat literary works barely no one

\footnotetext{
${ }^{(10)}$ Incited from the Keynote Speech by Prof. Kazuo of the University of T sukuba on Shandong - Japan Literary Seminar (Debut Release of Chinese Version of Armed Alley).
}

answered yes. In fact, it is not only international students from China, the Japanese students also hardly know about proletariat works. Haru ki Murakami has its special charms to echo with his Chinese readership by exploring the spiritual world of loneliness and confusion of urban people in the post-industrial civilization. But in the 21 st century, it is necessary for us to contemplate on the proletariat literature of Japan to pay attention to those moral writers' antimilitarist works. I recommend this novel to you. And I believe after reading the novel when you walking on the familiar streets and alleys and looking up to the monument at the Western Gate of Jinan commemorating 5. 3 Massacre, the novel will remind you of what has happened here and provokes your thought.

\section{REFERENCES}

[1] Armed Alley, by Kuroshima Denji (Japan), trans Li Guangzhen, Shandong People's Press, 2015.4 